\title{
INTAKES AND EXCRETIONS OF IRON, COPPER, AND ZINC IN THE NEONATAL PERIOD
}

\author{
BY \\ PATRICIA A. CAVELL and ELSIE M. WIDDOWSON \\ From the Medical Research Council Department of Experimental Medicine, University of Cambridge
}

(RECEIVED FOR PUBLICATION APRIL 20, 1964)

Rapid alterations in the distribution of iron, copper, and zinc within the body take place in the neonatal period, and the direction of the change is sometimes a reversal of that which has been going on during foetal life. Iron has attracted most attention because the fall in circulating haemoglobin that takes place in the weeks after birth can be measured comparatively easily. From time to time during the present century, however, investigators have measured the intakes and excretions of iron by babies in the first 6 months of life, often with the object of tracing the fate of the iron set free by the breakdown of red cells. Some of the infants have been breast fed, and others have received mixtures made up from cows ${ }^{\circ}$ or goats" milk: some have received supplements of one sort or another while others have had nothing but the milk in question. The results have been conflicting from first to last, even among investigators who have studied babies receiving breast milk and nothing else; no correlation has been found between the amount of iron set free from haemoglobin during the period of red cell destruction and the iron balance, and this cannot be attributed to faulty technique. The age and health of the baby and whether it was born prematurely or at term may be important. Langstein and Edelstein (1914) followed one breastfed baby through the first 12 days after birth and found that it was in negative balance for the first 7 days and in positive balance for the next 5 . Two other breast-fed babies aged 8 and 12 weeks were both in positive balance. Lichtenstein (1921) studied 4 premature babies receiving breast milk between the time they were 3 to 4 weeks and 4 months old. All the babies were in negative iron balance on every occasion. Wallgren (1933) had 5 breast-fed babies in his series. They were all studied on more than one occasion, the youngest age being 3 weeks, and the oldest 11 months: 3 babies were always in positive balance while the balances of the other 2 were sometimes negative, sometimes positive. Josephs (1934) measured the intakes and excretions of iron by 6 babies, but only 1 was breast fed: this baby retained a small amount of iron from the third to the fifth week but had a large negative balance over the next two months. Similarly, of the 14 infants studied by Stearns and Stinger (1937) only 1 was given human milk. At 9 and 13 weeks the excretion was equal to the intake. Maurer, Greengard, Curtis, and Klüver (1934) reported that 5 breast-fed infants aged 3 weeks to 3 months absorbed and retained $78-100^{\circ}$ of their iron intake; they and others (Stearns and McKinley, 1937) agree that babies having cows' milk preparations are more likely to be in negative iron balance than those that are breast fed.

The newborn period is the time of postnatal life when the anabolic tendency is at its greatest, and the young baby retains a higher proportion of most of the physiological constituents of its food than it is ever likely to do again (Slater, 1961). If babies really are frequently in negative iron balance the fact must be accepted, curious though it may seem, but little work has been done on the subject in recent years and a further investigation with rigid control seemed highly desirable.

The present study has been limited to the neonatal period, that is, to babies during the first 8 days after birth, and has embraced copper and zinc as well as iron. Only one study of copper metabolism at this age has been found (Kleinbaum 1962) and, apart from Berfenstam's (1952) report of the intake and faecal excretion of zinc by three babies with meningomyelocele, there seemed to be no information whatever about the baby's metabolism of zinc.

\section{Subjects and Methods}

Subjects. All babies studied in this investigation were born at the Cambridge Maternity Hospital. Meconium was collected for the first 24 hours after birth from 5 full-term girls and 1 boy. There were 10 normal full-term boys who were the subjects for the mineral balances, which were made at the end of the first week. 
These 10 babies were all doing well on breast milk and had received no supplement of any kind.

Meconium. Meconium was collected on weighed napkins made of polyethylene, which were changed as soon as possible after passage of a stool, and there was never any evidence that this was contaminated with urine. The napkins containing the stool were weighed and then washed with hot de-ionized water. The washings were carefully dried and the solids ground as finely as possible, avoiding mineral contamination. The total solids were weighed and duplicate samples (1-1.5 g.) were ashed in silica crucibles at $450=\mathrm{C}$. for mineral analyses.

Mineral Balances. These studies usually were made the time ran from the 5 th to the 7 th day, and for one baby only a 2-day balance was possible, on the 6 th and 7 th days. The procedures followed for the collection of the samples were, with a few modifications, those outlined by Widdowson, Cavell, and McKeag (1964). All samples were collected and stored in polyethylene bottles. De-ionized water was used for rinsing when necessary. The used napkins were washed as described (Widdowson et al., 1964), but de-ionized water and $\mathrm{HCl}$ were used. A sample of the acid solution used was kept as a blank on the washing procedure. The faeces and washings were homogenized by prolonged mechanical shaking in polyethylene containers, pooled, the total volume registered, and a measured portion of about one-tenth was taken for analysis.

The pooled volumes of milk and of urine were sampled as described by Widdowson et al. (1964), but $0.5 \mathrm{ml}$. $\mathrm{HNO}_{3}$ was added to each sample before ashing. All samples were carefully ashed in silica crucibles at $450^{\circ} \mathrm{C}$.

Blanks on the reagents were regularly carried out; the one for the milk and urine consisted of $0.5 \mathrm{ml} . \mathrm{HNO}_{3}$, and the one for the faeces of a volume of $\mathrm{HCl}$ solution equal to the volume taken for analysis.

Chemical Amalysis. After they had been ashed the samples of meconium, milk, urine, and faeces were treated alike. The ash was extracted by the method outlined by McCance ard Shipp (1933), but the filter paper was first washed with hot $50^{\circ}{ }_{0}\left(\frac{v}{v}\right) \mathrm{HCl}$ followed by de-ionized water, and the extraction was made with $1 \mathrm{ml}$. conc. $\mathrm{HCl}$ and $20 \mathrm{ml}$. $\mathrm{N} / 2 \mathrm{HCl}$. A similar procedure was followed with the residues from the two blanks from from the 6 th to the 8 th day after birth. For three babies

which the acid had been evaporated. De-ionized water was used throughout. The analyses were made on these ash extracts and all the analyses for an individual baby's balance study were carried out in one batch. Glassware, mainly pyrex to avoid contamination, was carefully washed with chromic acid and rinsed finally with deionized water. All pipettes and, as far as possible, other glassware were used only for the trace metal work. Silica crucibles were cleaned with dilute nitric acid before each use.

Iron was determined by the standard o-phenanthroline method as outlined by Sandell (1944). Copper was determined colorimetrically by the diethyldithio-carbamate method in which the colour was extracted from ammoniacal solution with amyl alcohol. The alcohol was siphoned off, dried by mixing with anhydrous sodium sulphate, and cleared by centrifuging. The colour was read at $435 \mu$ against alcohol and compared with standards carried through the procedure. This basic methcd was that of Eden and Green (1940). Zinc was determined as the dithizonate by the mixed colour method outlined by Sandell (1944). A set of standards was carried through this procedure for each balance.

\section{Results}

Excretion of Iron, Copper, and Zinc in Meconium During First 24 Hours After Birth. Table 1 shows the concentrations of iron, copper, and zinc in meconium passed by six babies in the first 24 hours after birth. The mean concentrations of iron and copper were approximately equal, that of zinc 4 times as high. The Table also shows the total excretions of the three elements. These values partly depend upon the amount of meconium the babies happened to pass in the first 24 hours, which varied from 20.7 to $47.7 \mathrm{~g}$. They do not represent the total amounts of the elements in the whole of the meconium filling the large intestine at the time of birth.

Iron, Copper, and Zinc in Breast Milk. Table 2 shows the concentrations of iron, copper, and zinc in the breast milk from the mothers whose babies were studied when they were 1 week old. It also gives the age of the baby, the mean weight, and the

TABLE 1

COMPOSITION AND EXCRETION OF MECONIUM IN THE FIRST 24 HOURS AFTER BIRTH

\begin{tabular}{|c|c|c|c|c|c|c|c|}
\hline \multirow[t]{2}{*}{ Baby No. } & \multirow{2}{*}{$\begin{array}{l}\text { Birth Weight } \\
\text { (kg.) }\end{array}$} & \multicolumn{3}{|c|}{$\begin{array}{l}\text { Composition of Meconium } \\
(\mathrm{mg} / 100 \mathrm{~g} \text {. wet weight })\end{array}$} & \multicolumn{3}{|c|}{$\begin{array}{l}\text { Excretion in Meconium During First } 24 \mathrm{hr} \text {. } \\
\text { (mg. kg. body weight) }\end{array}$} \\
\hline & & Iron & Copper & Zinc & Iron & Copper & Zinc \\
\hline $\begin{array}{c}1 \\
2 \\
3 \\
4 \\
5 \\
6 \\
\text { Mean }\end{array}$ & $\begin{array}{l}3 \cdot 65 \\
3 \cdot 37 \\
2 \cdot 94 \\
3 \cdot 74 \\
3 \cdot 65 \\
3 \cdot 12 \\
3 \cdot 41\end{array}$ & $\begin{array}{l}1 \cdot 67 \\
2 \cdot 71 \\
1 \cdot 75 \\
1 \cdot 20 \\
1 \cdot 45 \\
1 \cdot 31 \\
1 \cdot 68\end{array}$ & $\begin{array}{l}1 \cdot 70 \\
2 \cdot 47 \\
1 \cdot 53 \\
1 \cdot 75 \\
1 \cdot 80 \\
0 \cdot 95 \\
1 \cdot 70\end{array}$ & $\begin{array}{r}10 \cdot 02 \\
11 \cdot 73 \\
3 \cdot 63 \\
4 \cdot 16 \\
3 \cdot 88 \\
5 \cdot 57 \\
6 \cdot 50\end{array}$ & $\begin{array}{l}0 \cdot 16 \\
0 \cdot 17 \\
0 \cdot 15 \\
0 \cdot 13 \\
0 \cdot 19 \\
0 \cdot 16 \\
0 \cdot 16\end{array}$ & $\begin{array}{l}0 \cdot 16 \\
0 \cdot 15 \\
0 \cdot 13 \\
0 \cdot 19 \\
0 \cdot 24 \\
0 \cdot 12 \\
0 \cdot 17\end{array}$ & $\begin{array}{l}0.95 \\
1.08 \\
0.31 \\
0.44 \\
0.51 \\
0.69 \\
0.66\end{array}$ \\
\hline
\end{tabular}


TABLE 2

DESCRIPTION OF BABIES AND COMPOSITION OF BREAST MILK

\begin{tabular}{|c|c|c|c|c|c|c|}
\hline \multirow{2}{*}{ Baby No. } & \multirow{2}{*}{$\begin{array}{l}\text { Age During } \\
\text { Balance Period } \\
\text { (days) }\end{array}$} & \multirow{2}{*}{$\begin{array}{c}\text { Mean Weight } \\
\text { During Balance } \\
\text { Period (kg.) }\end{array}$} & \multirow{2}{*}{$\begin{array}{l}\text { Mean Milk Intake } \\
\text { During Balance } \\
\text { Period (ml. kg. day) }\end{array}$} & \multicolumn{3}{|c|}{ Composition of Breast Milk (mg. $100 \mathrm{ml}$ ) } \\
\hline & & & & Iron & Copper & Zinc \\
\hline $\begin{array}{c}7 \\
8 \\
9 \\
10 \\
11 \\
12 \\
13 \\
14 \\
15 \\
16 \\
\text { Mean }\end{array}$ & $\begin{array}{l}5-7 \\
5-7 \\
5-7 \\
6-7 \\
6-8 \\
6-8 \\
6-8 \\
6-8 \\
6-8 \\
6-8\end{array}$ & $\begin{array}{l}4 \cdot 13 \\
2 \cdot 63 \\
3 \cdot 12 \\
4 \cdot 04 \\
4 \cdot 27 \\
3 \cdot 22 \\
3 \cdot 10 \\
3 \cdot 24 \\
4 \cdot 47 \\
3 \cdot 59 \\
3 \cdot 58\end{array}$ & $\begin{array}{l}142 \\
156 \\
113 \\
175 \\
176 \\
207 \\
137 \\
170 \\
174 \\
148 \\
160\end{array}$ & $\begin{array}{l}0 \cdot 033 \\
0 \cdot 052 \\
0 \cdot 039 \\
0 \cdot 100 \\
0 \cdot 040 \\
0 \cdot 145 \\
0.060 \\
0.050 \\
0 \cdot 029 \\
0.041 \\
0.059\end{array}$ & $\begin{array}{l}0.066 \\
0.052 \\
0.058 \\
0.059 \\
0.071 \\
0.077 \\
0.061 \\
0.051 \\
0.055 \\
0.067 \\
0.062\end{array}$ & $\begin{array}{l}0 \cdot 142 \\
0 \cdot 168 \\
0 \cdot 343 \\
0 \cdot 645 \\
0 \cdot 677 \\
0 \cdot 573 \\
0 \cdot 506 \\
0 \cdot 157 \\
0 \cdot 265 \\
0 \cdot 600 \\
0 \cdot 408\end{array}$ \\
\hline
\end{tabular}

TABLE 3

IRON BALANCES (mg. kg. day)

\begin{tabular}{|c|c|c|c|c|c|c|}
\hline \multirow{2}{*}{ Baby No. } & \multirow{2}{*}{ Intake } & \multicolumn{3}{|c|}{ Excretion } & \multirow{2}{*}{$\begin{array}{c}\text { 'Absorption' } \\
\text { (Food - Faeces) }\end{array}$} & \multirow{2}{*}{ Balance } \\
\hline & & Faeces & Urine & Total & & \\
\hline $\begin{array}{c}7 \\
8 \\
9 \\
10 \\
11 \\
12 \\
13 \\
14 \\
15 \\
16 \\
\text { Mean }\end{array}$ & $\begin{array}{l}0.047 \\
0.080 \\
0.044 \\
0 \cdot 176 \\
0.070 \\
0 \cdot 302 \\
0.082 \\
0.085 \\
0.050 \\
0.061 \\
0 \cdot 100\end{array}$ & $\begin{array}{l}0 \cdot 568 \\
2 \cdot 422 \\
0 \cdot 457 \\
0 \cdot 758 \\
1 \cdot 071 \\
1 \cdot 165 \\
1 \cdot 188 \\
1 \cdot 760 \\
1 \cdot 357 \\
0 \cdot 477 \\
1 \cdot 122\end{array}$ & $\begin{array}{l}0 \cdot 001 \\
0 \cdot 001 \\
0 \cdot 002 \\
0 \cdot 002 \\
0 \cdot 001 \\
0 \cdot 003 \\
0 \cdot 001 \\
0 \cdot 001 \\
0 \cdot 003 \\
0 \cdot 002 \\
0 \cdot 002\end{array}$ & $\begin{array}{l}0 \cdot 569 \\
2 \cdot 423 \\
0 \cdot 459 \\
0 \cdot 760 \\
1 \cdot 072 \\
1 \cdot 168 \\
1 \cdot 189 \\
1 \cdot 761 \\
1 \cdot 360 \\
0 \cdot 479 \\
1 \cdot 124\end{array}$ & $\begin{array}{l}-0.521 \\
-2.342 \\
-0.413 \\
-0.582 \\
-1.001 \\
-0.863 \\
-1.106 \\
-1.675 \\
-1.307 \\
-0.416 \\
-1.022\end{array}$ & $\begin{array}{l}-0.522 \\
-2.343 \\
-0.415 \\
-0.584 \\
-1 \cdot 002 \\
-0.866 \\
-1 \cdot 107 \\
-1 \cdot 676 \\
-1 \cdot 310 \\
-0.418 \\
-1.024\end{array}$ \\
\hline
\end{tabular}

mean intake of milk over the balance period. The concentrations of iron and zinc varied more than that of copper, and there was little correlation between the concentrations of the three elements. The mean concentrations of iron and copper were similar to each other, and that of zinc four times as great. Feuillen and Plumier (1952) analysed a number of samples of breast milk for iron, and their range of values agrees with ours. The concentration of zinc is much higher in colostrum than in mature breast milk (Berfenstam, 1952); our values for the 5th to 8th day are in the same range as those of Berfenstam. Our mean values for all three metals are similar to those given by Macy, Kelly, and Sloan (1953), who also found, as we have, considerable variations between milk from different mothers. A high intake of milk has not necessarily coincided with low concentrations of the trace elements in it. Baby 12 in our series, for example, took twice as much milk per kg. of body weight as Baby 9, and his mother's milk had higher concentrations of iron, copper, and zinc. The intakes of the metals by the different babies during the balance period varied even more than either the concentrations of the elements in the milk or the volumes of milk taken by the babies.

Iron Balances. All the babies were in negative iron balance and the faeces contained 4 to 30 times as much as the food (Table 3 ). Only traces were excreted in the urine, and in most previous studies of iron balance in early life the urine has not even been collected, or has been included with the faeces. The average loss of iron from the body was just over $1 \mathrm{mg}$. $/ \mathrm{kg}$. day or $3.5 \mathrm{mg}$. day for an average baby. The excretion of iron in the faeces bore no relation to the amount in the food, and most of the faecal iron was clearly endogenous in origin. At the age of 1 week these babies were excreting about 7 times as much iron per day in the faeces as Babies 1-6 lost in the meconium during the first day after birth.

Copper Balances. Table 4 shows the intakes and excretions of copper by 10 babies 1 week old: 3 were in positive, and 5 in negative balance, and the total excretion was approximately equal to the intake in 2 . These results were similar to those of Kleinbaum (1962). Of his 6 full-term babies, 13 days old, 3 were in positive, and 3 in negative balance. The amount of copper in the urine, as of iron, was negligible and negative balances were always due to high faecal excretion. There was some relation between the amount of copper taken in the milk and the amount excreted in the faeces, and the highest intakes were associated with the greatest excretions. The daily quantities of copper in the faeces at 1 week of age were less than those in the meconium on the 
TABLE 4

COPPER BALANCES (mg. $/ \mathrm{kg}$. day)

\begin{tabular}{|c|c|c|c|c|c|c|}
\hline \multirow{2}{*}{ Baby No. } & \multirow{2}{*}{ Intake } & \multicolumn{3}{|c|}{ Excretion } & \multirow{2}{*}{$\begin{array}{c}\text { 'Absorption' } \\
\text { (Food - Faeces) }\end{array}$} & \multirow{2}{*}{ Balance } \\
\hline & & Faeces & Urine & Total & & \\
\hline $\begin{array}{c}7 \\
8 \\
9 \\
10 \\
11 \\
12 \\
13 \\
14 \\
15 \\
16 \\
\text { Mean }\end{array}$ & $\begin{array}{l}0 \cdot 095 \\
0.081 \\
0 \cdot 065 \\
0 \cdot 104 \\
0 \cdot 126 \\
0 \cdot 159 \\
0 \cdot 083 \\
0.088 \\
0.096 \\
0 \cdot 099 \\
0 \cdot 100\end{array}$ & $\begin{array}{l}0 \cdot 073 \\
0 \cdot 083 \\
0 \cdot 046 \\
0 \cdot 075 \\
0 \cdot 124 \\
0 \cdot 197 \\
0 \cdot 119 \\
0 \cdot 153 \\
0 \cdot 103 \\
0 \cdot 097 \\
0 \cdot 107\end{array}$ & $\begin{array}{c}0 \cdot 003 \\
\text { trace } \\
\text { trace } \\
\text { nil } \\
0 \cdot 002 \\
0 \cdot 003 \\
0 \cdot 001 \\
0 \cdot 001 \\
0 \cdot 003 \\
0 \cdot 002 \\
0 \cdot 002\end{array}$ & $\begin{array}{l}0 \cdot 076 \\
0 \cdot 083 \\
0 \cdot 046 \\
0 \cdot 075 \\
0 \cdot 126 \\
0 \cdot 200 \\
0 \cdot 120 \\
0 \cdot 154 \\
0 \cdot 106 \\
0 \cdot 099 \\
0 \cdot 109\end{array}$ & $\begin{array}{l}-0.022 \\
-0.002 \\
+0.019 \\
+0.029 \\
-0.002 \\
-0.038 \\
-0.036 \\
-0.065 \\
-0.007 \\
+0.002 \\
-0.007\end{array}$ & $\begin{array}{l}+0.019 \\
-0.002 \\
+0.019 \\
-0.029 \\
=0 \\
-0.041 \\
-0.037 \\
-0.066 \\
-0.010 \\
=0 \\
-0.009\end{array}$ \\
\hline
\end{tabular}

TABLE 5

ZINC BALANCES (mg. $/$ kg. day)

\begin{tabular}{|c|c|c|c|c|c|c|}
\hline \multirow{2}{*}{ Baby No. } & \multirow{2}{*}{ Intake } & \multicolumn{3}{|c|}{ Excretion } & \multirow{2}{*}{$\begin{array}{c}\text { 'Absorption' } \\
\text { (Food - Faeces) }\end{array}$} & \multirow{2}{*}{ Balance } \\
\hline & & Faeces & Urine & Total & & \\
\hline $\begin{array}{c}7 \\
8 \\
9 \\
10 \\
11 \\
12 \\
13 \\
14 \\
15 \\
16 \\
\text { Mean }\end{array}$ & $\begin{array}{l}0 \cdot 20 \\
0 \cdot 26 \\
0 \cdot 39 \\
1 \cdot 14 \\
1 \cdot 19 \\
1 \cdot 19 \\
0 \cdot 69 \\
0 \cdot 27 \\
0 \cdot 46 \\
0 \cdot 89 \\
0 \cdot 67\end{array}$ & $\begin{array}{l}0 \cdot 41 \\
0 \cdot 50 \\
0 \cdot 37 \\
1 \cdot 30 \\
1 \cdot 04 \\
1 \cdot 32 \\
0 \cdot 76 \\
1 \cdot 09 \\
0 \cdot 57 \\
0 \cdot 89 \\
0 \cdot 83\end{array}$ & $\begin{array}{l}0.05 \\
0.03 \\
0.12 \\
0.06 \\
0.07 \\
0.06 \\
0.09 \\
0.03 \\
0.08 \\
0.06 \\
0.07\end{array}$ & $\begin{array}{l}0.46 \\
0.53 \\
0.49 \\
1.36 \\
1.11 \\
1.38 \\
0.85 \\
1.12 \\
0.65 \\
0.95 \\
0.90\end{array}$ & $\begin{array}{l}-0.21 \\
-0.24 \\
+0.02 \\
-0.18 \\
-0.15 \\
-0.13 \\
-0.07 \\
-0.82 \\
-0.11 \\
=0 \\
-0.16\end{array}$ & $\begin{array}{l}-0 \cdot 26 \\
-0 \cdot 27 \\
-0 \cdot 10 \\
-0.22 \\
-0.08 \\
-0 \cdot 19 \\
-0 \cdot 16 \\
-0 \cdot 85 \\
-0 \cdot 19 \\
-0.06 \\
-0.23\end{array}$ \\
\hline
\end{tabular}

first day. The iron/copper ratios in meconium and in the faeces at 1 week of age were, therefore, very different, being about 1 and 10 , respectively.

Zinc Balances. The results for the zinc balances are given in Table 5. All but one were in negative balance. Most of the zinc was being excreted by the intestine and 7 of the babies had more in their faeces than in their food. The daily excretion of zinc by the bowel at 1 week of age was about the same as that during the first day. In all but one baby there was a relation between intake of zinc in the milk and its excretion in the faeces. About $8^{\circ}{ }_{0}$ of the total zinc excreted was found in the urine, and the mean concentration in infant's urine $(0.1 \mathrm{mg} . / 100 \mathrm{ml}$.) was about 5 times as high as that in adult urine (McCance and Widdowson, 1942).

\section{Discussion}

The outstanding question raised by the results of this study is how and why do babies at the end of the first week after birth excrete more iron and zinc in their stools than they get from their milk, and sometimes more copper as well? The quantities involved are considerable. Table 6 shows the approximate amounts of iron, copper, and zinc in the body of a baby weighing $3.5 \mathrm{~kg}$. (Widdowson and Spray, 1951 ; Widdowson and Dickerson, 1964), the mean daily intake of the three elements as found in this study, and the mean daily losses from the body. The baby gets from breast milk every day amounts equivalent to about $0 \cdot 1^{\circ}$ of its body iron, $2 \cdot 5 \%$ of its copper, and $4 \cdot 3^{\circ}$ of its zinc. The losses correspond to more than $1^{\circ}{ }_{o}$ of the body's iron and zinc and $0 \cdot 2^{\circ}$ of the copper. There is no evidence from the results of

TABLE 6

COMPARISON OF DAILY INTAKES AND LOSSES OF IRON. COPPER. AND ZINC WITH TOTAL AMOUNTS IN BODY

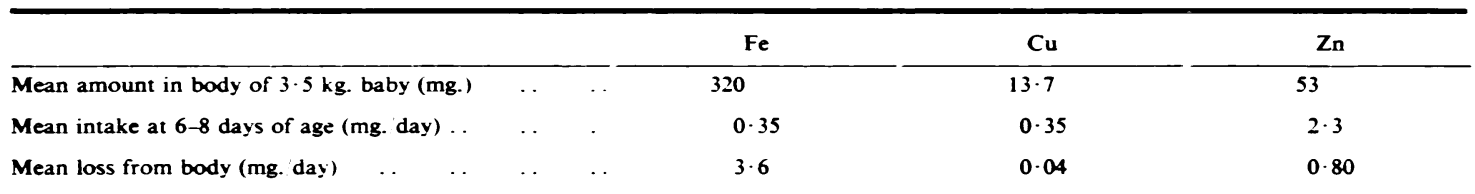


this investigation how long these losses continue, though they certainly continued for the 3 days of the study. On the face of it, it seems that losses as large as this must be a temporary phenomenon, peculiar to the neonatal period, for if this were not so the body would soon become seriously depleted. Haemolysed red blood cells are the probable source of the iron, and also of the zinc (Berfenstam 1952), but when iron is set free inside the body of an adult by the breakdown of red cells due to the administration of phenylhydrazine (McCance and Widdowson, 1937a) or in patients suffering from severe haemolytic anaemia (McCance and Widdowson, 1943; Granick, 1949), no significant amount of the iron is excreted. Indeed, iron once incorporated into the body of an adult is not excreted by the intestine in more than traces, and the amount of iron in the body is regulated by controlled absorption (McCance and Widdowson, 1937b; Maddock and Heath, 1939). The mechanism by which absorption is controlled is still not clearly understood (Lancet, 1963), but there seems no doubt that when erythropoietic activity is high iron absorption is increased, and conversely when it is low iron absorption is diminished (Bethard, 1962). In neither situation, however, do the faeces contain more iron than the food. This is evidently not the case in young babies, though why the iron and indeed the zinc and copper enter the intestine is not known. The bile is a possible source of the iron and copper, for Sheldon and Ramage $(1931,1933)$ using a spectrographic method found foetal bile to contain remarkably high concentrations of the two metals, and this may be the origin of some of the iron and copper in the meconium. Bile secreted by adults normally contains very little iron, but the concentration may increase during periods of intense haemolysis (Hawkins and Hahn, 1944). In the adult the iron reaching the intestine in the bile, or an equivalent amount derived from the food, must be reabsorbed if the person is to remain in iron balance even when there is extensive destruction of red cells going on inside the body. Josephs (1953) suggested that iron as it appears in the bile may be much more efficiently absorbed than other forms of the metal. Whether the bile of the young baby contains a particularly large amount of iron or whether the baby is less able than the adult to reabsorb this iron, or whether some other intestinal secretion is a more important source of the iron in the infant 's faeces still remains to be discovered.

Little may be known about the fundamental aspects of iron metabolism in the neonatal period, but still less information is available about the metabolism of copper and zinc, and speculation about it would be futile. Whether the loss of iron, copper, and zinc from the body in the neonatal period is peculiar to the human species, or whether it is true of other mammals is also not yet known. That it may be a more general phenomenon is suggested by the observations of Bertrand and Vladesco (1921) and Lintzel, Rechenberger, and Schairer (1944) who found that the amount of zinc and of iron in the body of the rabbit fell during the first few days after birth, and the finding of Manners and McCrea (1963) that pigs, 2 days old, contained less iron in their bodies than litter-mates at the time of birth.

\section{Summary}

Meconium passed during the first 24 hours after birth was collected from 6 babies and analysed for iron, copper, and zinc. The intake and urinary and faecal excretion of the three metals were measured on another 10 babies, all breast-fed, over a three-day period at the end of the first week.

Meconium contained an average of $1.7 \mathrm{mg} . / 100 \mathrm{~g}$. iron and copper and $6 \cdot 5 \mathrm{mg}$. $/ 100 \mathrm{~g}$. zinc.

The concentration of all three metals was very variable in breast milk and there was no relation between the volume of milk secreted and its composition.

All the babies were in negative iron balance: the faeces contained on the average more than 10 times as much iron as the food and the mean loss of iron from the baby's body amounted to $3 \cdot 6 \mathrm{mg}$. a day.

Some of the babies were in negative and some in positive copper balance, but all except one were in negative zinc balance. They were losing more than $1^{\circ}{ }_{0}$ of the body's total iron and zinc each day. It is not known how long these large negative balances continue, but possible explanations for them are discussed.

The authors are grateful to Dr. D. Gairdner for allowing these studies to be made on the babies in his care. They are very appreciative of the meticulous way in which Miss S. McKeag, Miss D. Smith, and Miss J. Harper collected the material, and are grateful to Miss D. Tinkler who performed her share of the chemical analysis.

\section{REFERENCES}

Berfenstam. R. (1952). Studies on blood zinc. Acta paediat. (Lppsala), 41. Suppl. 87.

Bertrand. G.. and Vladesco, R. (1921). Sur la variation de la teneur en zinc de lorganisme du lapin durant la croissance. C.R. Acad. Sci. (Paris). 173. 54.

Bethard. W. F. (1962). In Mechanisms of Anemia. ed. I. M. Weinstein, and E. Beutler, p. 157. McGraw-Hill. New York.

Eden. A., and Green, H. H. (1940). Micro-determination of copper in biological material. Biochem. J., 34, 1202.

Feuillen. Y. M., and Plumier, M. (1952). Iron metabolism in infants. I. The intake of iron in breast feeding and artificial feeding (milk and milk foods). Acta paediat. (Cppsala), 41, 138.

Granick. S. (1949). Iron metabolism and hemochromatosis. Bull. V.Y. Acad. Med.. 25. 403. 
Hawkins. W. B.. and Hahn. P. F. (1944). Biliary excretion of radioactive iron and total iron as influenced by red cell destruction J. exp. Med., 80. 31.

Josephs. H. W. (1934). Iron metabolism in infancy. Relation to nutritional anaemia. Bull. Johns Hopk. Hosp., 55, 259.

- (1953). Iron metabolism and the hypochromic anemia of infancy. Medicine (Baltimore), 32, 125.

Kleinbaum. H. (1962). Kupferstoffwechselbilanzen bei Säuglingen Z. Kinderheilk.. 87, 101.

Lancet (1963). Iron metabolism. 1. 428

Langstein. L.. and Edelstein, E. (1914). Der Eisenhaushalt im Sāuglingsalter. Mschr. Kinderheilk. (Referate), 12, 500.

Lichtenstein. A. (1921). Der Eisenumsatz bei Frühgeborenen. Acta paediat. (Lppsala), 1.194.

Lintzel. W.. Rechenberger. J., and Schairer. E. (1944). Uber den Eisenstoffwechsel des Neugeborenen und des Sāuglings. Z. ges. exp. Med.. 113, 591.

McCance. R. A., and Shipp, H. L. (1933). The chemistry of flesh foods and their losses on cooking. Spec. Rep. Ser. med. Res. Coun. (Lond.). No. 187.

- , and Widdowson, E. M. (1937a). The fate of the elements removed from the blood-stream during the treatment of polycythaemia by acetyl-phenylhydrazine. Quart. J. Med., 6. 277. 2. 680 .

(1942). The absorption and excretion of zinc. Biochem. J.. 36, 692.

, (1943). Iron excretion and metabolism in man. Nature (Lond.). 152.326.

Macy. I. G.. Kelly. H. J., and Sloan. R. E. (1953). The composition of milks. National Research Council Publ. 254 (A revision of Bulletin no. 119. 1950). Washington.

Maddock. S., and Heath. C. W. (1939). Is iron excreted by the gastrointestinal tract of the $\operatorname{dog}$ ? Arch. intern. Med., 63, 584.
Manners. M. J.. and McCrea. M. R. (1963). Changes in the chemical composition of sow-reared piglets during the lst month of life. Brit. J. Nutr., 17, 495.

Maurer. S., Greengard. J.. Curtis, W. L.. and Klüver. C. (1934). The effect of small quantities of breast milk. liver extract. iron and copper, respectively and in combinations. upon the iron balance of artificially fed infants. J. Pediat.. 4. 356.

Sandell. E. B. (1944). Colorimetric Determination of Traces of Metals. Interscience. New York.

Sheldon. J. H.. and Ramage. H. (1931). A spectrographic analysis of human tissues. Biochem. J., 25. 1608.

_- _- (1933). A spectrographic analysis of the metallic content of meconium. ibid.. 27, 674.

Slater, J. E. (1961). Retentions of nitrogen and minerals by babies one week old. Brit. J. Nutr., 15, 83

Stearns, G., and McKinley, J. B. (1937). The conservation of blood iron during the period of physiological hemoglobin destruction in early infancy. J. Nutr., 13, 143.

- and Stinger, D. (1937). Iron retention in infancy. ibid., 13, 127.

Wallgren. A. (1933). Le fer dans la nutrition de l'enfant. III Recherches sur le métabolisme du fer chez les enfants nourris au sein pendant la première année de leur existence. Rev. franc. Pédiat.. 9. 196.

Widdowson. E. M., Cavell. P. A.. and McKeag. S. (1964). Fat. nitrogen and mineral balances of young babies fed on breast milk or a preparation designed to simulate breast milk. Pediatrics. In the press.

- and Dickerson, J. W. T. (1964). Chemical composition of the body. In Mineral Metabolism, vol. 2. Part A, ed. C. L. Comar, and F. Bronner. Academic Press. New York.

. and Spray, C. M. (1951). Chemical development in utero. Arch. Dis. Childh., 26. 205. 